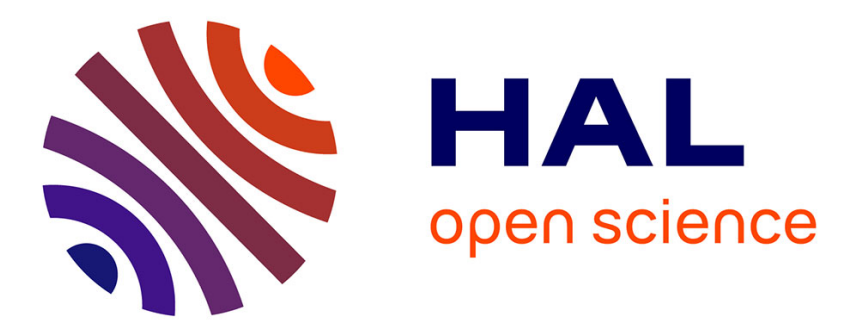

\title{
Effect of basic slag addition on soil properties, growth and leaf mineral composition of beans in a Cu-contaminated soil
}

\author{
O. Negim, B. Eloifi, C. Bes, H. Gaste, Mikael Motelica-Heino, Philippe Le \\ Coustumer
}

\section{To cite this version:}

O. Negim, B. Eloifi, C. Bes, H. Gaste, Mikael Motelica-Heino, et al.. Effect of basic slag addition on soil properties, growth and leaf mineral composition of beans in a $\mathrm{Cu}$-contaminated soil. Soil and Sediment Contamination, 2010, 19 (2), pp.174 - 187. 10.1080/15320380903548508 . insu-00399536

\section{HAL Id: insu-00399536 https://hal-insu.archives-ouvertes.fr/insu-00399536}

Submitted on 26 Jun 2009

HAL is a multi-disciplinary open access archive for the deposit and dissemination of scientific research documents, whether they are published or not. The documents may come from teaching and research institutions in France or abroad, or from public or private research centers.
L'archive ouverte pluridisciplinaire HAL, est destinée au dépôt et à la diffusion de documents scientifiques de niveau recherche, publiés ou non, émanant des établissements d'enseignement et de recherche français ou étrangers, des laboratoires publics ou privés. 


\title{
Effect of basic slag addition on soil properties, growth and leaf mineral composition of beans in a Cu-contaminated soil
}

\author{
NEGIM O. ${ }^{1}$, ELOIFI B. ${ }^{1}$, MENCH M. ${ }^{2}$, BES C. $^{2}$, GASTE H. ${ }^{2}$, MOTELICA-HEINO M. ${ }^{3}$ \\ and \\ LE COUSTUMER P. ${ }^{1}$
}

\begin{abstract}
${ }^{1}$ GHYMAC, Université Bordeaux 1, 33405 Talence, France
${ }^{2}$ UMR BIOGECO INRA 1202 Ecologie des Communautés, Université Bordeaux 1, Bat B8 RdC Est, avenue des Facultés, 33405, Talence, France.

${ }^{3}$ ISTO, UMR 6113, CNRS Université d'Orléans, France.
\end{abstract}

\section{ABSTRACT}

Basic slag (BS) is an alkaline by-product of the steel industry with potential properties to ameliorate nutrient supply and metal stabilisation in contaminated soils. The BS effects on soil $\mathrm{pH}$, soil conductivity, growth and chemical composition of beans were investigated using an acid, sandy soil from a wood treatment facility containing $630 \mathrm{mg} \mathrm{Cu} \mathrm{kg}{ }^{-1}$. Pot experiments were carried out on a 2-week period with Phaseolus vulgaris L. An uncontaminated, sandy soil was used as a control (CTRL). BS was added into the soil (1 $\mathrm{kg}$ soil pot $\left.{ }^{-1}\right)$ to constitute four treatments in triplicates: $0 \%$ (T1), $1 \%$ (T2), $2 \%$ (T3) and $4 \%$ (T4) BS kg-1 air-dried soil. The BS addition increased soil $\mathrm{pH}$, soil conductivity, and plant growth compared to the untreated soil. At $1 \%$ and $2 \%$ BS addition rate, highest shoot yields (dry weight, DW) occurred. Foliar $\mathrm{Cu}$ concentration varied from $5.6 \mathrm{mg} \mathrm{kg}^{-1}$ to $53.1 \mathrm{mg} \mathrm{kg}^{-1}$ in the following order: CTRL $<\mathrm{T} 2, \mathrm{~T} 3, \mathrm{~T} 4<\mathrm{T} 1$. The highest decrease in the foliar $\mathrm{Cu}$ concentration, 2.3 times compared to T1 plants, was obtained for the T2 plants. The BS addition at $1 \%$ rate into 
the $\mathrm{Cu}$-contaminated soil promoted bean growth with the lowest foliar $\mathrm{Cu}$ concentration. Foliar Ca concentration was enhanced in the T2, T3 and T4 treatments whereas the foliar P concentration was not promoted.

Keywords: basic slag, Cu, in situ stabilisation, liming, soil remediation, Phaseolus vulgaris.

\section{INTRODUCTION}

In contaminated soils, stabilisation technique aims at decreasing the labile pool of metals and metalloids such as $\mathrm{As}, \mathrm{Cr}, \mathrm{Cu}, \mathrm{Pb}, \mathrm{Cd}$ and $\mathrm{Zn}$ by the incorporation of amendments. This technique is able to enhance one or several processes such as metal adsorption through increased surface charge, formation of organic and inorganic metal complexes, sorption on $\mathrm{Fe}, \mathrm{Mn}$, and $\mathrm{Al}$ oxides, and precipitation. It can be used in in situ and ex situ applications to reclaim and re-vegetate industrially devastated areas and mine-spoils, restore the physical, chemical, and biological soil properties, and reduce the contaminant mobility and bioavailability with various chemical and mineralogical agents such as industrial by-products (Bolan and Duraisamy, 2003; Pérez de Mora et al., 2005; Raicevic et al., 2005; Kumpiene et al., 2008). Elements such as $\mathrm{As}, \mathrm{Cu}, \mathrm{Cr}$, and $\mathrm{Zn}$ can be found in excess in contaminated soils at wood treatment facilities, especially when $\mathrm{Cu}$ sulphates and chromated copper arsenate (CCA) were used as a preservative against insects and fungi, which may result in soil phytotoxicity (Kumpiene et al., 2008). The As stabilisation can occur through sorption on Fe oxides by replacing the surface hydroxyl groups with the As ions, and also by the formation of amorphous Fe (III) arsenates and/or insoluble secondary oxidation minerals. The $\mathrm{Cr}$ immobilisation mostly deals with Cr reduction from toxic and mobile hexavalent form Cr (VI) to stable Cr (III) in natural environments. Copper immobilisation by clays, organic matter, carbonates, phosphates, and Fe oxides amendments was reported with precipitation of $\mathrm{Cu}$ 
carbonates and oxy-hydroxides, ion exchange and the formation of ternary cation-anion complexes on the surface of Fe and $\mathrm{Al}$ oxy-hydroxides (Kumpiene et al., 2008). Phosphorus amendments, clays, birnessite and coal fly ash such as beringite can successfully immobilise Zn in soil (Mench et al., 2000; Bolan et al., 2003; Kumpiene et al., 2008).

Several alkaline slags have been used for amending acid soils. Phosphogypsum can improve soil properties such as $\mathrm{pH}$, soil electrical conductivity (EC), cation exchange capacity (CEC), exchangeable Ca, Mg, and metal availability to plant, and increase the crop yield (Alva and Sumner, 1990). Slag treatments increase more soil $\mathrm{pH}$ than converter sludge treatments (Kiaee Jamali et al., 2005). Combination of slag and converter sludge treatments enhances the plant $\mathrm{Ca}$ and $\mathrm{Mg}$ concentrations. The application of calcium silicate slag reduces the soil acidity and increases available P, Si and exchangeable Ca in soil. (Barbosa Filho et al., 2004). Blast furnace slag are used to correct soil acidity and can promote root growth and distribution in the soil profile, which results in higher shoot dry matter and grain yield of upland rice under sprinkler irrigation (Carvalho-Pupatto et al., 2004). A combination of converter slag and fungicide does not decrease the density of dormant spores of Plasmodiophora brassicae in the soil but suppresses the clubroot disease (Murakami and Goto, 2004). The application of Linz-Donawitz (LD) slag in acid soils managed under pastures increases the soil $\mathrm{pH}$ with and without NPK fertilization (Pinto et al., 1995), enhances exchangeable soil $\mathrm{Ca}$ and $\mathrm{Mg}$ whereas exchangeable soil $\mathrm{Al}, \mathrm{Mn}, \mathrm{Cu}$ and $\mathrm{Zn}$ decrease (Besga et al., 1996), and its combination with NPK fertilizers results in highest crop yields and nutrient concentrations in plants (Lopez et al., 1995). Both calcitic limestone and basic slag (BS) applied in Brazil sugarcane fields generate a beneficial residual effect in the correction of soil acidity, the increase of base saturation, and the yield of sugar cane rattoon (Prado et al., 2003). For Ali and Shahram, (2007), the increasing rate of soil pH is 
proportional to the slag amount used. The slag decreases Fe availability at a pH range of 7.4 8.5 but increases it at higher $\mathrm{pH}$, while the slag use also proportionately enlarges the $\mathrm{P}$ and Mn availability. In greenhouse studies the application of $1 \%$ and $2 \%(w / w)$ of slag in tea garden soil and 0.5, 1 and $2 \%$ slag in rice field soil enhances the plant shoot DW yield and P and Mn uptake. Fe and $\mathrm{K}$ uptake increases in rice field, $\mathrm{K}$ uptake declines in tea garden soil and Fe uptake is not changed. The addition of Thomas basic slag (TBS), hydrous manganese oxide (HMO), iron grit and beringite to a contaminated soil does not raise the plant biomass production but reduces the mobility and bioavailability of $\mathrm{Cd}, \mathrm{Zn}$ and $\mathrm{Pb}$ (Mench et al., 1994a, b). These agents effectively mitigate the Cd uptake by plants. In ryegrass, HMO and iron grit decrease either shoot $\mathrm{Pb}$ or $\mathrm{Zn}$ concentrations, and TBS reduces shoot $\mathrm{Pb}$ concentrations. The application of alkaline materials, organic matters, phosphates, aluminosilicates, iron grit, basic slag (3.9\%) and compost of sewage sludge (5\%) combined with iron grit are the most efficient to promote shoot production and limit foliar $\mathrm{Cu}$ accumulation in dwarf beans cultivated in a highly Cu-contaminated soil (Bes and Mench, 2008).

The Ca and $\mathrm{P}$ contents in BS make it a potential liming agent to increase the precipitation and sorption of metals such as $\mathrm{Cu}$ and a potential fertilizer promoting plant growth and improving physico-chemical properties of the soil. Therefore this study aimed at investigating a BS addition into a soil mainly Cu-contaminated from a wood treatment facility and which addition rate may improve soil characteristics such as $\mathrm{pH}$ and EC and reduce the labile pool of trace elements in soil for root-to-shoot transfer in beans. Hypotheses were that BS compounds may influence the composition of soil solution through acid-base, precipitation and sorption reactions, and foliar concentrations through changes in soil solution, competitions for root uptake and root-to-shoot transfer. Bean plants were cultivated in potted soils with increasing BS addition rates, from $0 \%$ to $4 \%$, placed in controlled 
conditions. Changes in soil EC and $\mathrm{pH}$, plant growth, biomass production and the foliar elemental concentrations of primary leaves were determined.

\section{MATERIAL AND METHODS}

\subsection{Soil characterisation}

The topsoil (0-0.25 m) mainly contaminated by $\mathrm{Cu}$ was sampled from a French wood treatment facility (Mench and Bes, 2009). This anthropogenic soil developed on an alluvial soil in terrace (Fluviosol) containing alluvial materials from the Garonne River combined with wind deposits (BRGM, 1978). Copper contamination originated mainly from $\mathrm{Cu}$ sulphate and in a lesser extent from standard CCA type C (copper oxide $11.1 \%$ w/w, chromium trioxide $30 \% \mathrm{w} / \mathrm{w}$, arsenic pentoxide $19.9 \% \mathrm{w} / \mathrm{w}$ ) used as wood preservatives (Bes and Mench, 2008; Mench and Bes, 2009). The soil was air-dried and sieved at $2 \mathrm{~mm}$. A sandy control soil from the same soil type was sampled $(0-0.25 \mathrm{~m})$ in an uncontaminated kitchen garden, Gradignan, France. A soil aliquot (50 g) was used for particle size distribution analysis by sieving and pipette methods (Richards, 1954). The soil $\mathrm{pH}$ was measured in 1:1 soil:water suspension using a glass electrode pH meter (Jackson, 1967). The soil electrical conductivity (EC) was measured in 1:1 soil: water suspension by using the glass electrode (Jackson, 1967). Total nitrogen was determined at the INRA laboratorie d'Analyses des sols (LAS), Arras, France using standard methods (Inra Las, 2007). The organic matter content was determined by a modified Walkely-Blake method; $0.5 \mathrm{~g}$ soil was placed in a $500-\mathrm{ml}$ conical flask and mixed with $10 \mathrm{ml}$ of $0.17 \mathrm{M} \mathrm{K}_{2} \mathrm{Cr}_{2} \mathrm{O}_{7}$ followed by addition of $20 \mathrm{ml}$ of $\mathrm{H}_{2} \mathrm{SO}_{4}$, $200 \mathrm{ml}$ of water, $10 \mathrm{ml}$ of $\mathrm{H}_{3} \mathrm{PO}_{4}$ and one $\mathrm{ml}$ of diphenylamine indicator. Finally the contents were titrated with $0.5 \mathrm{M} \mathrm{FeSO}_{4} \cdot 7 \mathrm{H}_{2} 0$. The estimation of organic matter assumes that $77 \%$ of the organic carbon is oxidized by the method and that soil organic matter contains

58\% C (Jackson, 1967). The cation exchange capacity (CEC) was determined using 
cobaltihexamine chloride (Ciesielski and Sterckeman, 1997). Total metal contents in soil were determined by ICP-AES after wet digestion in $\mathrm{HF}$ and $\mathrm{HCIO}_{4}($ AFNOR NF X 31-147, Ciesielski et al., 1997). Table 1 lists physico-chemical properties of contaminated and control soils.

\subsection{Basic slag characterisation}

BS is a by-product of the steel industry, containing mainly calcium oxide, silicon oxide, iron oxide, and other metal oxides. They were determined by using an atomic absorption spectrophotometer (Rank Hilger, Atom Spek H-1580). Arsenic (As) was analysed by GF-AAS according to norm NF EN ISO 15586 (T90-119) after digestion with regal water (NF EN 13346), other trace elements were analysis by ICP-AES according to norm NF EN ISO 11885 after mineralisation (total digestion NFX31-147). The $\mathrm{pH}$ and electrical conductivity (EC) for BS were measured in 1:1 BS: water suspension by using $\mathrm{pH}$ meter and glass electrode EC respectively. The BS characterisation is shown in Table 2

\subsection{Pot experiment}

Four soil treatments were prepared by mixing soil (1 kg air-dried weight) with $0 \%, 1$ $\%, 2 \%$ and $4 \%$ of BS. Amended soils (made in triplicates) were homogenised by rotation in 2-L plastic flasks, transferred into 1.3-L plastic pots, then watered daily and maintained at 70 $\%$ of water holding capacity (WHC, $10 \%$ of soil air-dried weight) by manual irrigation with distilled water and allowed to react for four weeks at $20^{\circ} \mathrm{C}$. The control soil was treated in the same way. Four dwarf beans (Phaseolus vulgaris L. cv vroege Limburgs) were sown in all pots and cultivated (15 days) in controlled conditions: illumination $12 \mathrm{~h}$ light/12 h darkness regime, intensity $150 \mu \mathrm{mol} \mathrm{m} \mathrm{s}^{-1}$, temperature $25^{\circ} \mathrm{C} / 22^{\circ} \mathrm{C}$, and $50 \%$ relative humidity. Pots were arranged in a fully randomised block design on a bench and watered daily with 
deionised water to $70 \%$ WHC to maintain the soil in the $50-70 \%$ WHC range during the day without loss from drainage. The plant growth was monitored on a daily basis using an index based on plant development steps for two weeks and then plants were harvested. Biometrical parameters, i.e. fresh weight (FW) of roots, shoots, and primary leaves were measured. Plant materials were washed with deionised water (2 times) and distilled water, oven dried at $70{ }^{\circ} \mathrm{C}$, and weighted to determine the DW biomass production. Plant samples $(0.5 \mathrm{~g})$ were wet digested in $5 \mathrm{~mL} 14 \mathrm{M} \mathrm{HNO}_{3}, 2 \mathrm{~mL} \mathrm{H}_{2} \mathrm{O}_{2}$ and $1 \mathrm{~mL}$ distilled water at $180^{\circ} \mathrm{C}$ in $\mathrm{PFA}$ (perfluoroalkoxy copolymer resin) tubes under microwaves (MarXpress, CEM). Mineral composition in plant digests were measured by ICP-AES (Ultima, Jobin Yvon Horiba, Longjumeau, France). The soil samples were taken from all pots experiment to measure the soil $\mathrm{pH}$ and the EC in suspension soil:distilled water in the ratio 1:1 using a glass electrode $\mathrm{pH}$ meter and electrical conductivity respectively (Jackson, 1967).

\section{$\underline{2.4 \text { Statistics }}$}

The soil properties and plant yield, element concentrations and total element amount in primary leaves [ $\mu \mathrm{g}$ plant $^{-1}$, so-called here element accumulation and calculated based on foliar element concentration ( $\mu \mathrm{g} \mathrm{kg}{ }^{-1} \mathrm{DW}$ ) and leaf biomass production ( $\mu \mathrm{g} \mathrm{DW}$ plant $^{-1}$ ) of plants from the pot experiment were tested by statistical analysis (ANOVA, Kruskall-Wallis and Tukey test) with SAS software version 9.1.

\section{RESULTS AND DISCUSSION}

\subsection{Soil parameters}

The BS incorporation in soil study increased the soil $\mathrm{pH}$ in relation with the addition rate from 5.6 for the $\mathrm{T} 1$ treatment to $7.9,8.3$ and 9.8 for the $\mathrm{T} 2$, $\mathrm{T} 3$, and $\mathrm{T} 4$ treatments, respectively. This resulted in soil $\mathrm{pH}$ values higher in the T2, T3, and $\mathrm{T} 4$ treatments than in 
the control soil (7.0) (Figure 1). Increase in soil $\mathrm{pH}$ was predicted by a polynomial equation (y $\left.=-0.223 x^{2}+1.883 x+5.774, R^{2}=0.96\right)$. Ali and Shahram, (2007) found that the increasing rate of soil $\mathrm{pH}$ was proportional to the slag amount used in soil. Basic slag affected also the soil EC which increased from (in $\mathrm{mS} \mathrm{cm}^{-1}$ ) 0.14 (T1) to $0.39,0.46$ and 0.82 for the T2, T3, and T4 treatments respectively. Consequently, soil EC was lower in the T1, T2 and T3 treatments and higher in $\mathrm{T} 4$ than in the control soil $\left(0.62 \mathrm{mS} \mathrm{cm}^{-1}\right)$ (Figure 2). A linear equation predicted the increase in soil EC in relation with the BS addition rate $(y=0.161 \mathrm{x}+$ $\left.0.176, \mathrm{R}^{2}=0.97\right)$. The enhanced soil $\mathrm{pH}$ and EC in amended soils were likely due to the alkaline property and composition of BS. Su and Evans, (1996) reported that EC increased in soil treated with lime. Amelioration of acid soils with amendments such as alkaline byproducts can improve soil properties such as pH and EC (Alva and Sumner, 1990). Our results are in line with Pinto et al. (1995) who reported that BS application in acid soils increased the soil $\mathrm{pH}$ with and without NPK fertilization. In addition, the incorporation of Thomas basic slag into a Cu-contaminated topsoil from a wood treatment facility increased soil pH (Bes and Mench, 2008). Our results confirmed BS as a potential liming agent able to improve the soil acidity. An 1\% addition rate would correspond to 25000-30000 kg BS ha ${ }^{-1}$ depending of the soil depth considered, i.e. 0.25 or $0.3 \mathrm{~m}$. Rodriguez et al. (1994) suggested that LinzDonawitz (LD) slag application increased soil pH linearly, especially where fertilizer was not applied. The $7500 \mathrm{~kg}$ addition rate, without NPK fertilization, increased soil pH from 5.3 to 6.5. When $3000 \mathrm{~kg} \mathrm{ha}^{-1}$ of slag was added, the increase in soil $\mathrm{pH}$ was accompanied by a decrease of $\mathrm{Al}$ saturation percentage in the cation exchange complex to $<10 \%$.

\subsection{Plant analysis}




\subsubsection{Plant yield}

Some basic slags previously used in acid soils have ameliorated plant growth and their biomass production (Lopez et al., 1995). Shoot yield DW are presented in Figure 3. The effect of BS incorporation into the soil on the biomass of bean primary leaves varied across the treatments. The shoot yield was the highest for the control soil and the lowest for the T1 treatment. This confirmed that the studied soil negatively impacted beans (Bes and Mench, 2008). Shoot yield numerically increased for all amended soils. Compared to the untreated soil (T1), T2 and T3 treatments delivered the highest increases for the shoot yield, i.e. 1.89 and 1.75 times for $\mathrm{T} 2$ and $\mathrm{T} 3$, while the $\mathrm{T} 4$ treatments gave an intermediate value. These values for shoot yields in the T2 and T3 treatment corresponded to $89 \%$ and $83 \%$ based on the control soil value. Only the difference between T1 and T2 treatments however was statistically significant. In previous findings, the application of respectively $1 \%$ and $2 \%$ $(\mathrm{w} / \mathrm{w})$ of the slag in tea garden soil and $0.5,1$ and $2 \%$ slag in rice field soil increased the plant shoot DW yield (Ali and Shahram, 2007). The application of Linz-Donawitz (LD) slag in acid soils combination with NPK fertilizers resulted also in highest crop yields (Lopez et al., 1995). The decrease in shoot yield for the T4 treatment compared to the T2 and T3 treatments likely indicated an excessive BS addition rate. The ideal soil $\mathrm{pH}$ for beans is in the 6.0-7.5 range (Gardener’s Network, 2009) and soil pH for the T4 treatment largely exceeded these values. In addition the soil conductivity in the $0-0.45 \mathrm{mS} \mathrm{cm}^{-1}$ range is suitable for most plants if recommended fertilizers are used, but a high conductivity $\left(0.46-0.7 \mathrm{mS} \mathrm{cm}^{-1}\right)$ may reduce the emergence and cause a slight to severe damage to salt sensitive plants (Omafra, 2008). Indeed the soil EC in the T4 treatment which reached $0.8 \mathrm{mS} \mathrm{cm}^{-1}$ would be excessive and may contribute to limit bean shoot yields. 
The BS effect on the root DW yield varied with its addition rate in soil (Figure 4). The highest value of the root DW yield occurred in the T2 treatment and the lowest value in the T1 treatment. Root yield was significantly higher in T2 and T3 BS-amended soils than in the untreated soil (T1) and control soil (CTRL). The differences however remained relatively low. For the T2 and T3 treatments, the root yield increased 1.06 and 1.05 times respectively compared to the untreated soil (T1). Higher increases in root biomass were previously obtained with the addition of Thomas basic slag (TBS) in a Cu-contaminated soil from a wood treatment facility (Bes and Mench, 2008) and of blast furnace slag to upland rice (Carvalho-Pupatto et al., 2004). At 4\% addition rate, the beneficial BS effect on root yield disappeared again likely due to excessive increases in soil pH and EC.

\subsubsection{Foliar element concentrations and accumulations}

The effect of BS addition rate in soil on the foliar element concentrations and foliar element accumulations are presented in Tables 3 and 4 respectively.

\subsubsection{Foliar nutrient concentrations and accumulations}

Foliar Al concentration decreased in plants from all BS-amended soils. Its value was significantly lower in T3 plants than in T1 plants, reaching the control level. The decrease in foliar $\mathrm{Al}$ concentration is likely due to the liming effect, i.e. the rise in the soil $\mathrm{pH}$ and competition with $\mathrm{Ca}$ for root uptake, and increase in primary leaf biomass. The foliar $\mathrm{Al}$ accumulation varied in the 1.2-3.3 $\mu$ glant $^{-1}$ range with lowest and highest values for $\mathrm{T} 3$ and T2 plants but differences were not significant. Foliar Mg concentration was higher in T1 plants than in control plants likely due to a lower leaf biomass. The increase in the leaf biomass for the T2 and T3 beans reduced foliar Mg concentration. In addition, the rise of foliar Ca concentration may induce a decrease in foliar Mg concentration. Changes in foliar Mg accumulation were not significant. The Ca concentration was 3 times lower in the primary 
leaves of $\mathrm{T} 1$ beans than that in control beans. It was also below frequent values for primary leaf $\mathrm{Ca}$ concentrations in dwarf beans. In the literature, $1 \%$ slag and $1 \%$ converter sludge treatments increased Ca and Mg concentration in the plant (Kiaee Jamali et al., 2005). Bes and Mench (2008) suggested that the low foliar Ca concentration vs. foliar $\mathrm{Cu}$ concentration can limit bean growth. The foliar Ca concentration was increased 8.9 times for both T2 and T3 plants compared to T1 plants and 2.7 times compared to the control plants. This reflected the Ca inputs in studied soil due to the BS incorporation. It decreased in T4 plants probably because roots were negatively impacted by the high soil EC value. The foliar Ca accumulation lined up according to the order: T1 $<$ CTRL, T4 $<$ T2, T3. The Foliar P concentrations were ranked as follows: T2, T3 $<$ T4 $<$ CTRL, T1. The control soil contained relatively a high organic matter content which could supply organic P and was regularly fertilized. Both low leaf yield for the T1 plant and acid soil pH in T1 treatment could likely enhance the foliar $\mathrm{P}$ concentration. Despite P inputs in soil due to the BS incorporation, the foliar P concentration was not increased in beans from BS-amended soils. We assumed that several soil and plant factors can explain this result. Firstly, the BS contained a high Ca content and relatively high Fe and Al contents. Therefore phosphates could be sorbed with these three cations and not easily available in the soil solution for root uptake. Increase in the leaf yield could contribute to reduce foliar P concentration in T2 and T3 beans. Regarding foliar P accumulation, plants from untreated and BS-treated soils have a lower value than the control soil. The foliar $\mathrm{K}$ concentration increased in relation with the BS addition rate but differences were only significant between $\mathrm{T} 4$ plants and the other plants. The foliar $\mathrm{K}$ concentration was 1.8 times and 1.5 times higher in T4 plants than in T1 plants and control plants, respectively. This slightly exceeded frequent values for foliar K concentration in bean primary leaves. However in plants the critical K concentration is in the 20-50 $\mathrm{g} \mathrm{kg}^{-1} \mathrm{DW}$ range (Marschner, 1995). The 
foliar $\mathrm{K}$ accumulation was similar in T2, T3, T4 and CTRL. Only the T1 plants showed a decrease in foliar $\mathrm{K}$ accumulation compared to all other plants.

\subsubsection{Foliar trace element concentrations and accumulations}

The foliar $\mathrm{Cu}$ concentration varied from $5.6 \mathrm{mg} \mathrm{kg}^{-1}$ to $53.1 \mathrm{mg} \mathrm{kg}^{-1}$ in the following order: CTRL $<\mathrm{T} 2, \mathrm{~T} 3, \mathrm{~T} 4<\mathrm{T} 1$. The foliar $\mathrm{Cu}$ concentration in $\mathrm{T} 1$ plants exceeded its frequent values and the critical $\mathrm{Cu}$ concentration for bean leaves, i.e. $15-30 \mathrm{mg} \mathrm{Cu} \mathrm{kg}^{-1} \mathrm{DW}$ (MacNicol and Beckett, 1985). We assumed that this mainly caused the phytotoxic effect in plants grown in the untreated, Cu-contaminated soil. The highest decrease in the foliar $\mathrm{Cu}$ concentration, i.e. 2.3 times compared to the T1 plants, was obtained for the T2 plants. This suggested that the $\mathrm{Cu}$ labile pool for root uptake in the soil is low at the $\mathrm{T} 2$ soil $\mathrm{pH}$ and that further increase in the soil $\mathrm{pH}$ for the $\mathrm{T} 3$ and $\mathrm{T} 4$ treatments may enhance $\mathrm{Cu}$ complexation with dissolved organic matter (DOM) in the soil solution (Sauvé et al., 1997). The mobility of copper in soil depended on several factors, including the Cu-complexing ability of the solid phase, the Cu-complexing ability of the DOM, and the molecular weight of the DOM fractions (Han and Thompson, 2003). Cu-DOM complexation increases approximately 10-fold per $\mathrm{pH}$ unit ( $\mathrm{Lu}$ and Allen, 2002). However the availability of such Cu-DOM complexes for root uptake in T3 and T4 soils is questionable. The BS addition at $1 \%$ into the studied soil promoted bean growth with the lowest foliar $\mathrm{Cu}$ concentration and highest Ca concentrations. Foliar $\mathrm{Cu}$ accumulation varied from $0.4 \mathrm{mg}$ to $2.0 \mathrm{mg} \mathrm{plant}^{-1}$ in the following order: CTRL < T4, T2, T3, T1. Indeed the $\mathrm{Cu}$ amount accumulated in primary leaves was not significantly changed in plants from BS-treated soils, but their improved shoot yield resulted in reducing foliar $\mathrm{Cu}$ concentrations through a biomass dilution effect. The rise in foliar Ca accumulation in BS-treated plants may contribute to a better pectin methylesterase functioning (Micheli, 2001), resulting in the restoration of cell elongation and a higher Cu sorption on the cell walls. 
Restoration of Ca homeostasis may also promote plant metabolism and the $\mathrm{Cu}$ sorption by various ligands (Pilon et al., 2006). Changes in foliar Zn concentration were not significant across the treatments. Foliar Zn concentration exceeded its frequent values in some dwarf beans from BS-treated soils but remained below the critical leaf concentration for dwarf beans i.e. $100 \mathrm{mg} \mathrm{kg}^{-1} \mathrm{DW}$ (Mench et al., 2000). Usually an increase in soil $\mathrm{pH}$ reduces $\mathrm{Zn}$ availability in the soil solution and changes in the leaf yield affect the foliar $\mathrm{Zn}$ concentration causing a decrease in foliar Zn concentration (Mench et al., 2000). For instance the addition of Thomas BS decreases the mobility and bioavailability of $\mathrm{Cd}, \mathrm{Zn}$ and $\mathrm{Pb}$ in a highly contaminated soil, near smelters at Evin (Pas de Calais, France) (Mench et al., 1994a). But here our results did not confirm such previous studies. The foliar $\mathrm{Cr}$ concentration was not significantly changed in BS-treated soils compared with the control soil, and all values fell in the range of $\mathrm{Cr}$ frequent values. The foliar $\mathrm{Cr}$ accumulations were also similar for all treatments. Foliar Cd concentration and accumulation decreased below the analytical detection limits with the BS application compared with the untreated soil.

\section{CONCLUSION}

A basic slag (BS) was incorporated at increasing addition rates (1, 2 and 4\%) in an acid sandy Cu-contaminated soil. The soil $\mathrm{pH}$ was increased from 5.6 in the untreated soil up to 9.8 for the $4 \%$ BS-amended soil. The soil conductivity rose from $0.14 \mathrm{mS} \mathrm{cm}^{-1}$ in the untreated soil to $0.38 \mathrm{mS} \mathrm{cm}{ }^{-1}, 0.46 \mathrm{mS} \mathrm{cm}^{-1}$, and $0.82 \mathrm{mS} \mathrm{cm}^{-1}$ in the $1 \%, 2 \%$, and $4 \%$ BSamended soils respectively. These increases in soil pH and EC in all BS-amended soils likely resulted from the BS composition and in particular its high Ca content. The pot experiment carried out with dwarf beans demonstrated that (i) the foliar Cu concentration likely caused a phytotoxic effect in plants grown in the untreated, Cu-contaminated soil, (ii) the BS incorporation at $1 \%$ addition rate into the contaminated soil promoted bean growth with the 
lowest foliar $\mathrm{Cu}$ concentration and highest Ca concentrations, and (iii) foliar P concentration however was not enhanced by the BS incorporation into the Cu-contaminated soil. Instead, foliar $\mathrm{K}$ accumulation in primary leaves was restored up to control level. Therefore this byproduct was effective at $1 \%$ addition rate as a liming material but not as a $\mathrm{P}$ fertilizer in this short-term experiment. The BS incorporation in the contaminated soil did not increase the foliar concentrations and accumulations for $\mathrm{Cd}, \mathrm{Cr}$, and $\mathrm{Zn}$.

\section{REFERENCES}

Ali, M. T., and Shahram, S.H. 2007. Converter slag as a liming agent in the amelioration of acidic soils. International Journal of Agriculture and Biology 9, 5, 715-720.

Alva, A.K., and Sumner, M.E.1990. Amelioration of acid soil infertility by phosphogypsum. Plant and Soil 128, 2, 127-129.

Barbosa Filho, M.P., Zimmermann F.J.P., and Da Silva, O.F. 2004. Influence of calcium silicate slag on soil acidity and upland rice grain yield. Cienciae Agrotecnologia 28, 2, 323-331.

Bes C., and Mench, M. 2008. Remediation of copper-contaminated topsoils from a wood treatment facility using in situ stabilisation. Environmental Pollution 156, 3, 11281138.

Besga, G., Pinto, M., and Rodriguez, M. 1996. Agronomic and nutritional effects of LinzDonawitz slag application to two pastures in Northern Spain. Nutrient Cycling in Agroecosystems 46, 3, 157-167.

Bolan, N.S., Adriano, D.C., and Naidu, R. 2003. Role of phosphorus in im- and mobilization and bioavailability of heavy metals in the soil-plant system. Reviews of Environmental Contamination and Toxicology 177, 1-44. 
Bolan N.S., and Duraisamy, V.P. 2003. Role of inorganic and organic soil amendments on immobilisation and phytoavailability of heavy metals: a review involving specific case studies. Australian Journal of Soil Research 41, 3, 533-555.

BRGM, 1978. Graves Entre-deux-Mers, Carte géologique de la France à 1/50000, Pessac XV37, Bureau de recherches géologiques et minières, Orléans, France.

Carvalho-Pupatto, J.G., Bull, L.T., and Crusciol, C.A.C. 2004. Soil chemical attributes, root growth and rice yield according to slag application. Pesquisa Agropecuaria Brasileria 39, 12, 1213-1218.

Ciesielski H., Proix, N., and Sterckeman, T. 1997. Détermination des incertitudes liées à une méthode de mise en solution des sols et des sédiments par étude interlaboratoire. Analusis 25, 6, 188-192.

Ciesielski, H., and Sterckeman, T. 1997. Determination of cation exchange capacity and exchangeable cations in soils by means of cobalt hexamine trichloride. Effects of experimental conditions. Agronomie, 17, 1, 1-7.

Gardener’s Network. 2009. pH levels in garden soils, pH levels for vegetables. http://www.gardenersnet.com/atoz/phlevel1.htm (May 4, 2009).

Han, N., and Thompson M. L. 2003. Impact of dissolved organic matter on copper mobility in aquifer material. Environmental Quality 32, 5, 1829-1836.

Inra Las, 2007. Laboratoire d'analyses des sols d'Arras. Méthodes employées au laboratoire. http://www.arras.inra.fr/pages/methode-du-las-sols.htm.

Jackson, M. L. 1967. Soil Chemical Analysis, Prentice-Hall., Inc., Englewood Cliffs, New Jersey, USA.

Kiaee Jamali, S. F., Forghani, A., and Shirinfekr, A. 2005. Effects of slag and converter sludge of Isfahan iron melting factory on some properties of an acid soil under tea planting. Journal of Agriculture Sciences 1, 6, 71-82. 
Kumpiene J., Lagerkvist, A., and Maurice, C. 2008. Stabilization of As, Cr, $\mathrm{Cu}, \mathrm{Pb}$ and $\mathrm{Zn}$ in soil using amendments - A review. Waste Management 28, 1, 215-225.

Lopez, F.A., Balcazar, N., and Formoso, A. 1995. The recycling of Linz-Donwitz (LD) converter slag by use as a liming agent on pasture land. Waste Management and Research 13, 6, 555-568.

Lu, Y. F., and Allen, H. E.2002. Characterization of copper complexation with natural dissolved organic matter (DOM) - link to acidic moieties of DOM and competition by Ca and Mg. Water Research 36, 20, 5083-5101.

MacNicol, R.D., and Beckett, P.H.T. 1985. Critical tissue concentrations of potentially toxic elements. Plant and Soil 85, 1, 107-129.

Marschner, H. 1995. Mineral Nutrition in Higher Plants, $2^{\text {nd }}$ ed. Academic Press, London, p. 889.

Mench, M., and Bes, C. 2009. Assessment of the ecotoxicity of topsoils from a wood treatment site. Pedosphere 19, 2, 143-155.

Mench, M., Coussin, F., Mocquot, B., Bussière, S., Prunet, T., and Lagriffoul, A. 1996. Evaluation des apports d'un biotest végétal et de la spéciation des éléments traces à la mise au point d'une batterie de tests d'écotoxicologie terrestre applicables aux sols et aux déchets. Sous-thème : Biotest végétal. Final report n4930029, INRA, Unité d'Agronomie, Bordeaux - ADEME, Recherche, Milieux et Impact, Paris, France. 43p.

Mench, M., Didier, V., Löffler, M., Gomez, A., and Masson, P., 1994b. A mimicked in-situ remediation study of metal-contaminated soils with emphasis on cadmium and lead. Journal of Environmental Quality 23, 58-63. 
Mench, M., Manceau, A., Vangronsveld, J., Clijsters, H., and Mocquot, B. 2000. Capacity of soil amendments in lowering the phytoavailability of sludge-borne zinc, Agronomie 20, 4, 383-397.

Mench, M., Vangronsveld, J., Didier, V., and Clijsters, H., 1994a. Evaluation of metal mobility, plant availability and immobilization by chemical agents in a limed-silty soil. Environmental Pollution 86, 3, 279-286.

Micheli, F. 2001. Pectin methylesterases: cell wall enzymes with important roles in plant physiology. Trends in Plant Science 6, 9, 414-419.

Murakami, K., and Goto, I. 2004. Effect of controlling the clubroot disease of sugukina by the application of converter slag for soil amendments. Japanese Journal of Soil Science and Plant Nutrition 75, 2, 233-235.

Omafra., 2008. The Gardener's Handbook. Chapter 4: The Nature of Soil. Look to the Ground (http://www.omafra.gov.on.ca/english/crops/gardbk/4soil.htm\#table7).

Pérez de Mora A., Ortega-Calvo, J. J., Cabrera E., and Madejón, F. 2005. Changes in enzyme activities and microbial biomass after "in situ" remediation of a heavy metalcontaminated soil. Applied Soil Ecology 28, 2,125-137.

Pilon, M., Abdel-Ghany, S.E., Cohu, C. M., Gogolin, K. A., and Ye, H. 2006. Copper cofactor delivery in plant cells. Current Opinion in Plant Biology 9, 3, 256-263.

Pinto, M., Rodriguez, M., Besga, G., K.K., and Lopez, F.A. 1995. Effects of Linz-Donowitz (LD) slag on soil properties and pasture production in the Basque country (Northern Spain). New Zealand Journal of Agricultural Research 38, 1, 143-155.

Prado, R.M., Fernandes, F.M., and Natale, W. 2003. Residual effect on calcium silicate slag as soil acidity corrective in sugar cane rattoon. Revista Brasileria de Ciencia Do Solo 27, 2, 287-296. 
Raicevic S., Kaludjerovic-Radoicic, T., and Zouboulis, A.I. 2005. In situ stabilization of toxic metals in polluted soils using phosphates: theoretical prediction and experimental verification. Journal of Hazardous Materials 117, 1, 41-53.

Richards, L.A., 1954. Diagnosis and improvement of saline and alkali soil. United States Department of Agriculture, Handbook 60, Washington DC, USA. http://www.ars.usda.gov/SP2UserFiles/Place/53102000/hb60_pdf/hb60intro.pdf

Rodriguez M., Lopez, F. A., Pinto, M., Balcazar, N., and Besga, G. 1994. Basic Linz Donawitz slag as a liming agent for pastureland. American Society of Agronomy 86, 5, 904-909.

Sauvé, S., McBride, M., Norvell, W.A., and Hendershot, W. 1997. Copper solubility and speciation of in situ contaminated soils: Effects of copper level, $\mathrm{pH}$ and organic matter. Water, Air and Soil Pollution 100, 1-2, 133-149.

Su, C., and Evans, L. J. 1996. Soil solution chemistry and alfalfa response to $\mathrm{CaCO}_{3}$ and $\mathrm{MgCO}_{3}$ on an acidic Gleysol. Canadian Journal of Soil Science 76, 1, 41-46. 
Table 1: Physico-chemical properties of contaminated and control soils.

\begin{tabular}{|c|c|c|}
\hline Parameters & Contaminated soil & Control soil \\
\hline Particle size distribution & & \\
\hline Sand $\%$ & 88.8 & 66.5 \\
\hline Silt \% & 4.8 & 15.5 \\
\hline Clay \% & 6.4 & 18.0 \\
\hline $\mathrm{pH}$ & 5.64 & 7.01 \\
\hline $\mathrm{EC} \mathrm{mS} \mathrm{cm}{ }^{-1}$ & 0.11 & 0.62 \\
\hline Total nitrogen $(\mathrm{N}) \mathrm{g} \mathrm{kg}^{-1}$ & 0.693 & 2.94 \\
\hline Organic carbon $\mathrm{g} \mathrm{kg}^{-1}$ & 14.8 & 40.4 \\
\hline $\mathrm{C} / \mathrm{N} \%$ & 21.3 & 13.8 \\
\hline Organic matter $\mathrm{g} \mathrm{kg}^{-1}$ & 25.6 & 69.9 \\
\hline CEC $\mathrm{cmol}^{+} \mathrm{kg}^{-1}$ & 1.94 & 16.1 \\
\hline As $\mathrm{mg} \mathrm{kg}^{-1}$ & 27.4 & 3.6 \\
\hline Co mg kg ${ }^{-1}$ & 3.37 & 2.62 \\
\hline Cr $\mathrm{mg} \mathrm{kg}^{-1}$ & 41.9 & 17.9 \\
\hline $\mathrm{Cu} \mathrm{mg} \mathrm{kg}^{-1}$ & 630 & 21.5 \\
\hline Mn mg kg & 147 & 189 \\
\hline $\mathrm{Ni} \mathrm{mg} \mathrm{kg}$ & 8.31 & 7.46 \\
\hline Zn mg kg ${ }^{-1}$ & 42.3 & 50.9 \\
\hline
\end{tabular}

Table 2: Characterisation of the basic slag

\begin{tabular}{|c|c|}
\hline $\begin{array}{l}\text { pH } \\
\text { EC } \mathrm{mS} / \mathrm{cm}\end{array}$ & $\begin{array}{c}12.72 \\
12.2 \\
\end{array}$ \\
\hline $\begin{array}{l}\mathrm{Al}_{2} \mathrm{O}_{3} \% \\
\mathrm{CaO} \% \\
\mathrm{Fe}_{2} \mathbf{O}_{3} \% \\
\mathrm{~K}_{2} \mathrm{O} \% \\
\mathrm{MgO} \% \\
\mathrm{MnO} \% \\
\mathbf{P}_{2} \mathbf{O}_{5} \% \\
\mathrm{SiO}_{2} \% \\
\mathrm{TiO}_{2} \%\end{array}$ & $\begin{array}{c}5.91 \\
60.69 \\
14.61 \\
0.15 \\
2.51 \\
1.06 \\
1.05 \\
12.54 \\
1.47\end{array}$ \\
\hline As mg/kg & $<5$ \\
\hline Co mg/kg & $<5$ \\
\hline Ni mg/kg & $<10$ \\
\hline Cu mg/kg & 5 \\
\hline Zn mg/kg & 42 \\
\hline Pb mg/kg & $<20$ \\
\hline Mn \% & 0.01 \\
\hline
\end{tabular}


Table 3: Element concentrations in the primary leaves of bean plants.

\begin{tabular}{|c|c|c|c|c|c|c|}
\hline Treatments & $\mathbf{T 1}$ & $\mathbf{T} 2$ & T3 & T4 & CTRL & $\begin{array}{l}\text { Frequent } \\
\text { values (\#) }\end{array}$ \\
\hline Al $\mathrm{mg} / \mathrm{kg}$ & $\begin{array}{c}0.07 \mathrm{a} \\
\pm 0.01^{*}\end{array}$ & $\begin{array}{l}0.04 \mathrm{ab} \\
\pm 0.02 *\end{array}$ & $\begin{array}{c}0.02 \mathrm{~b} \\
\pm 0.01^{*}\end{array}$ & $\begin{array}{l}0.04 \mathrm{ab} \\
\pm 0.01^{*}\end{array}$ & $\begin{array}{c}0.03 \mathrm{~b} \\
\pm 0.01^{*}\end{array}$ & - \\
\hline Mg g/kg & $\begin{array}{c}3.14 \mathrm{a} \\
\pm 0.10^{* * *}\end{array}$ & $\begin{array}{c}1.93 \text { c } \\
\pm 0.20^{* * *}\end{array}$ & $\begin{array}{c}1.93 \mathrm{c} \\
\pm 0.15^{* * *}\end{array}$ & $\begin{array}{c}2.18 \mathrm{c} \\
\pm 0.03^{* * *}\end{array}$ & $\begin{array}{c}2.51 \mathrm{~b} \\
\pm 0.21^{* * *}\end{array}$ & $1.9-3.7$ \\
\hline Ca g/kg & $\begin{aligned} & 3.37 \mathrm{~d} \\
\pm & 1.03^{* * *}\end{aligned}$ & $\begin{array}{c}29.41 \mathrm{a} \\
\pm 3.21^{* * *}\end{array}$ & $\begin{array}{c}29.45 \mathrm{a} \\
\pm 1.37 * * *\end{array}$ & $\begin{array}{c}21.54 \mathrm{~b} \\
\pm 1.77^{* * *}\end{array}$ & $\begin{array}{c}10.97 \text { с } \\
\pm 1.95^{* * *}\end{array}$ & $6.4-29$ \\
\hline P g/kg & $\begin{array}{c}5.24 \mathrm{a} \\
\pm 0.52^{* *}\end{array}$ & $\begin{array}{c}3.16 \mathrm{~b} \\
\pm 0.55^{* *}\end{array}$ & $\begin{array}{c}3.30 \mathrm{~b} \\
\pm 0.41^{* *}\end{array}$ & $\begin{array}{c}4.23 \mathrm{ab} \\
\pm 0.42^{* *}\end{array}$ & $\begin{array}{c}4.82 \mathrm{a} \\
\pm 0.14^{* *}\end{array}$ & $1-6$ \\
\hline K g/kg & $\begin{array}{c}16.01 \mathrm{~b} \\
\pm 1.23^{* *}\end{array}$ & $\begin{array}{c}18.62 \mathrm{~b} \\
\pm 2.78^{* *}\end{array}$ & $\begin{array}{c}21.17 \mathrm{~b} \\
\pm 2.16^{* *}\end{array}$ & $\begin{array}{c}29.77 \mathrm{a} \\
\pm 3.95^{* *}\end{array}$ & $\begin{array}{c}19.31 \mathrm{~b} \\
\pm 0.13^{* *}\end{array}$ & $13-22$ \\
\hline Cd $\mathrm{mg} / \mathrm{kg}$ & $\begin{array}{c}0.11 \mathrm{a} \\
\pm \\
0.10 \mathrm{NS}\end{array}$ & $<\mathrm{dl}$ & $<\mathrm{dl}$ & $<\mathrm{dl}$ & $<\mathrm{dl}$ & $0.03-0.07$ \\
\hline Cr mg/kg & $\begin{array}{c}0.41 \mathrm{a} \\
\pm 0.09 \mathrm{NS}\end{array}$ & $\begin{array}{c}0.33 \text { a } \\
\pm 0.11 \text { NS }\end{array}$ & $\begin{array}{c}0.61 \mathrm{a} \\
\pm 0.27 \mathrm{NS}\end{array}$ & $\begin{array}{c}0.65 \mathrm{a} \\
\pm 0.07 \mathrm{NS}\end{array}$ & $\begin{array}{c}1.70 \mathrm{a} \\
\pm 1.02 \mathrm{NS}\end{array}$ & $0.13-1.7$ \\
\hline Cu mg/kg & $\begin{array}{c}53.13 \mathrm{a} \\
\pm 14.04 * *\end{array}$ & $\begin{array}{c}22.59 \mathrm{~b} \\
\pm 1.59 * *\end{array}$ & $\begin{array}{c}27.54 \mathrm{~b} \\
\pm 1.51^{* *}\end{array}$ & $\begin{array}{c}27.64 \mathrm{~b} \\
\pm 0.71^{* *}\end{array}$ & $\begin{array}{c}5.65 \mathrm{c} \\
\pm 0.67 * *\end{array}$ & $4.9-7.9$ \\
\hline Zn mg/kg & $\begin{array}{c}25 \mathrm{a} \\
\pm 14 \mathrm{NS}\end{array}$ & $\begin{aligned} & 31.5 \mathrm{a} \\
\pm & 20.5 \mathrm{NS}\end{aligned}$ & $\begin{array}{c}16.5 \mathrm{a} \\
\pm 3.5 \mathrm{NS}\end{array}$ & $\begin{array}{c}24 \mathrm{a} \\
\pm 12 \mathrm{NS}\end{array}$ & $\begin{array}{c}12 \mathrm{a} \\
\pm 2.5 \mathrm{NS}\end{array}$ & $13-20$ \\
\hline
\end{tabular}

- In a column mean values ( \pm standard deviations) followed by the same letter do not differ significantly $\mathrm{P}(0.05<*<0.01), \mathrm{P}(0.01<* *<0.001), \mathrm{P}(0.001<* * *<0.0001)$ and non significant NS $(\mathrm{p}>0.05)$.

- (\#) ranges of frequent values for element concentrations in the primary leaves of dwarf bean grown on uncontaminated control soils (Mench et al., 1996).

$-<$ dl: detection limit.

Table 4: Element accumulation in the primary leaves of bean plants $\left(\mu \mathrm{g}_{\text {plant }}{ }^{-1}\right)$

\begin{tabular}{|c|c|c|c|c|c|}
\hline Treatments & T1 & T2 & T3 & T4 & CTRL \\
\hline Al & $\begin{aligned} & 2.87 \mathrm{a} \\
\pm & 1.28 \mathrm{NS}\end{aligned}$ & $\begin{aligned} & 3.31 \mathrm{a} \\
\pm & 2.26 \mathrm{NS}\end{aligned}$ & $\begin{aligned} & 1.18 \mathrm{a} \\
\pm & 0.25 \mathrm{NS}\end{aligned}$ & $\begin{aligned} & 2.16 \mathrm{a} \\
\pm & 0.97 \mathrm{NS}\end{aligned}$ & $\begin{aligned} & 2.28 \mathrm{a} \\
\pm & 0.40 \mathrm{NS}\end{aligned}$ \\
\hline Mg & $\begin{array}{c}119 \mathrm{a} \\
\pm \\
4 \text { NS }\end{array}$ & $\begin{array}{c}138 \text { a } \\
\pm 16 \text { NS } \\
\end{array}$ & $\begin{array}{c}128 \text { a } \\
\pm 30 \text { NS } \\
\end{array}$ & $\begin{array}{c}117 \text { a } \\
\pm 25 \text { NS } \\
\end{array}$ & $\begin{array}{r}195 \text { a } \\
\pm 34 \text { NS } \\
\end{array}$ \\
\hline Ca & $\begin{array}{c}127 \mathrm{c} \\
\pm 49 * * * \\
\end{array}$ & $\begin{array}{c}2140 \mathrm{a} \\
\pm 531 * * * \\
\end{array}$ & $\begin{array}{c}1950 \mathrm{a} \\
\pm 430 * * * \\
\end{array}$ & $\begin{array}{c}1170 \mathrm{~b} \\
\pm 337 * * * \\
\end{array}$ & $\begin{array}{c}843 \mathrm{~b} \\
\pm 71^{* * *} \\
\end{array}$ \\
\hline $\mathbf{P}$ & $\begin{array}{l}198 \mathrm{~b} \\
\pm 57^{*}\end{array}$ & $\begin{array}{l}225 \mathrm{~b} \\
\pm 27^{*}\end{array}$ & $\begin{array}{l}214 \mathrm{~b} \\
\pm 22^{*}\end{array}$ & $\begin{array}{l}224 \mathrm{~b} \\
\pm 29^{*}\end{array}$ & $\begin{array}{l}377 \text { a } \\
\pm 87^{*}\end{array}$ \\
\hline $\mathbf{K}$ & $\begin{array}{c}602 \mathrm{~b} \\
\pm 151^{*}\end{array}$ & $\begin{array}{l}1354 \text { a } \\
\pm 343^{*}\end{array}$ & $\begin{array}{l}1405 \text { a } \\
\pm 361 *\end{array}$ & $\begin{array}{l}1583 \mathrm{a} \\
\pm 260^{*}\end{array}$ & $\begin{array}{l}1521 \mathrm{a} \\
\pm 406^{*}\end{array}$ \\
\hline Cd & $\begin{aligned} & 0.01 \mathrm{a} \\
\pm & 0.01 \mathrm{NS}\end{aligned}$ & $<\mathrm{dl}$ & $<\mathrm{dl}$ & $<\mathrm{dl}$ & $<\mathrm{dl}$ \\
\hline $\mathrm{Cr}$ & $\begin{array}{c}0.02 \mathrm{a} \\
\pm 0.01 \mathrm{NS}\end{array}$ & $\begin{array}{c}0.02 \mathrm{a} \\
\pm 0.01 \mathrm{NS} \\
\end{array}$ & $\begin{array}{c}0.04 \mathrm{a} \\
\pm 0.02 \mathrm{NS} \\
\end{array}$ & $\begin{array}{c}0.03 \mathrm{a} \\
\pm 0.003 \mathrm{NS}\end{array}$ & 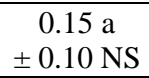 \\
\hline $\mathrm{Cu}$ & $\begin{aligned} & 2.04 \mathrm{a} \\
& \pm 0.80 \mathrm{NS} \\
&\end{aligned}$ & $\begin{aligned} & 1.63 \mathrm{a} \\
& \pm 0.32 \mathrm{NS} \\
&\end{aligned}$ & $\begin{aligned} & 1.81 \mathrm{a} \\
& \pm 0.34 \mathrm{NS} \\
&\end{aligned}$ & $\begin{aligned} & 1.48 \mathrm{a} \\
& \pm 0.27 \mathrm{NS} \\
&\end{aligned}$ & $\begin{aligned} & 0.43 \mathrm{~b} \\
& \pm 0.06 \mathrm{NS} \\
&\end{aligned}$ \\
\hline Zn & $\begin{array}{c}0.92 \mathrm{a} \\
\pm 0.04 \mathrm{NS}\end{array}$ & $\begin{aligned} & 2.26 \mathrm{a} \\
\pm & 1.08 \mathrm{NS}\end{aligned}$ & $\begin{array}{c}1,07 \mathrm{a} \\
\pm 0.06 \mathrm{NS}\end{array}$ & $\begin{array}{c}1.27 \mathrm{a} \\
\pm 0.8 \mathrm{NS}\end{array}$ & $\begin{array}{c}0.94 \mathrm{a} \\
\pm 0.03 \mathrm{NS}\end{array}$ \\
\hline
\end{tabular}

- In a column (mean values \pm standard deviations) followed by the same letter do not differ significantly $\mathrm{P}(0.05<*<0.01), \mathrm{P}(0.001<* * *<0.0001)$ and non significant NS $(\mathrm{P}>0.05)$.

- <dl: detection limit. 


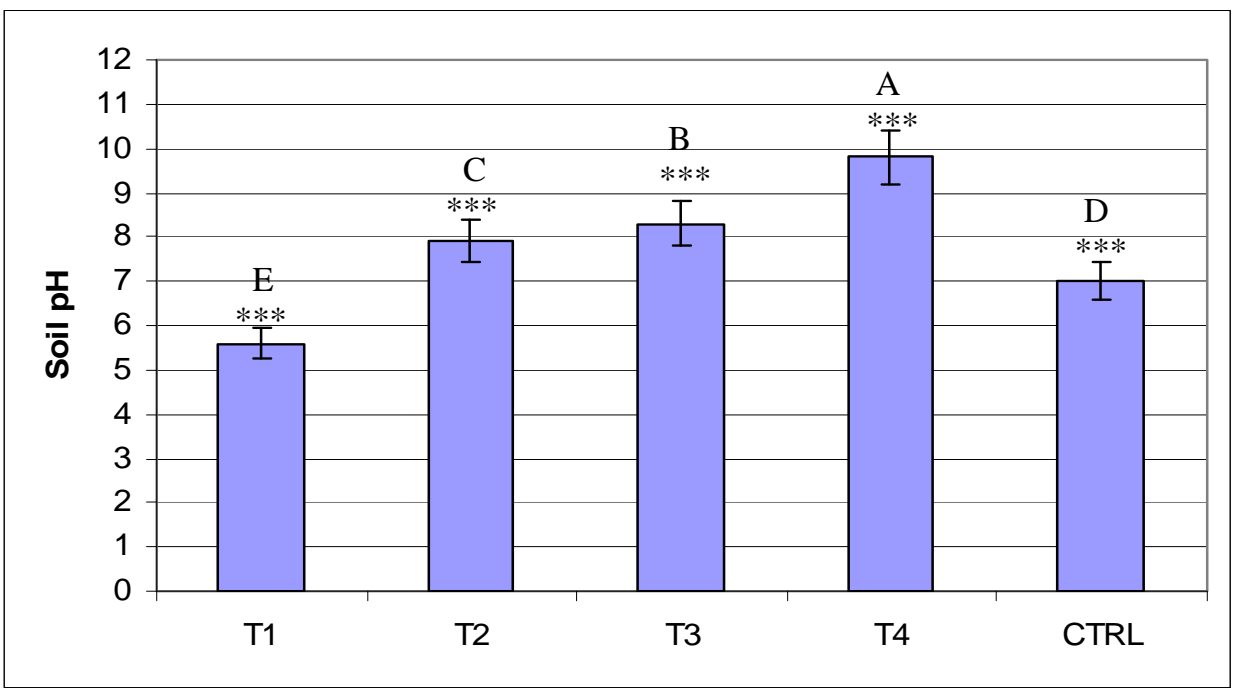

Values are mean \pm standard errors $(n=3)$. Bar graphs with different letters were significantly difference; P $(0.001<* * *<0.0001)$.

Fig. 1: Effects of basic slag on the soil pH

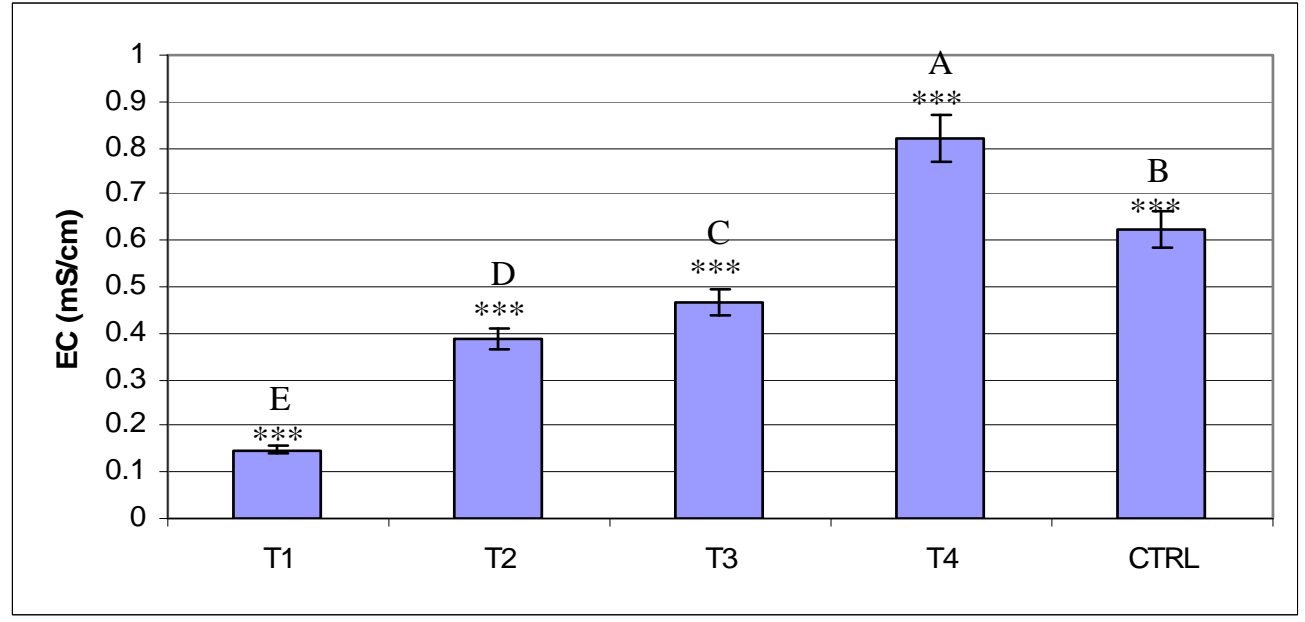

Values are mean \pm standard errors $(n=3)$. Different letters on bar graphs indicate a significant difference; $\mathrm{P}(0.001<* * *<0.0001)$.

Fig. 2: Effects of basic slag on the soil EC 


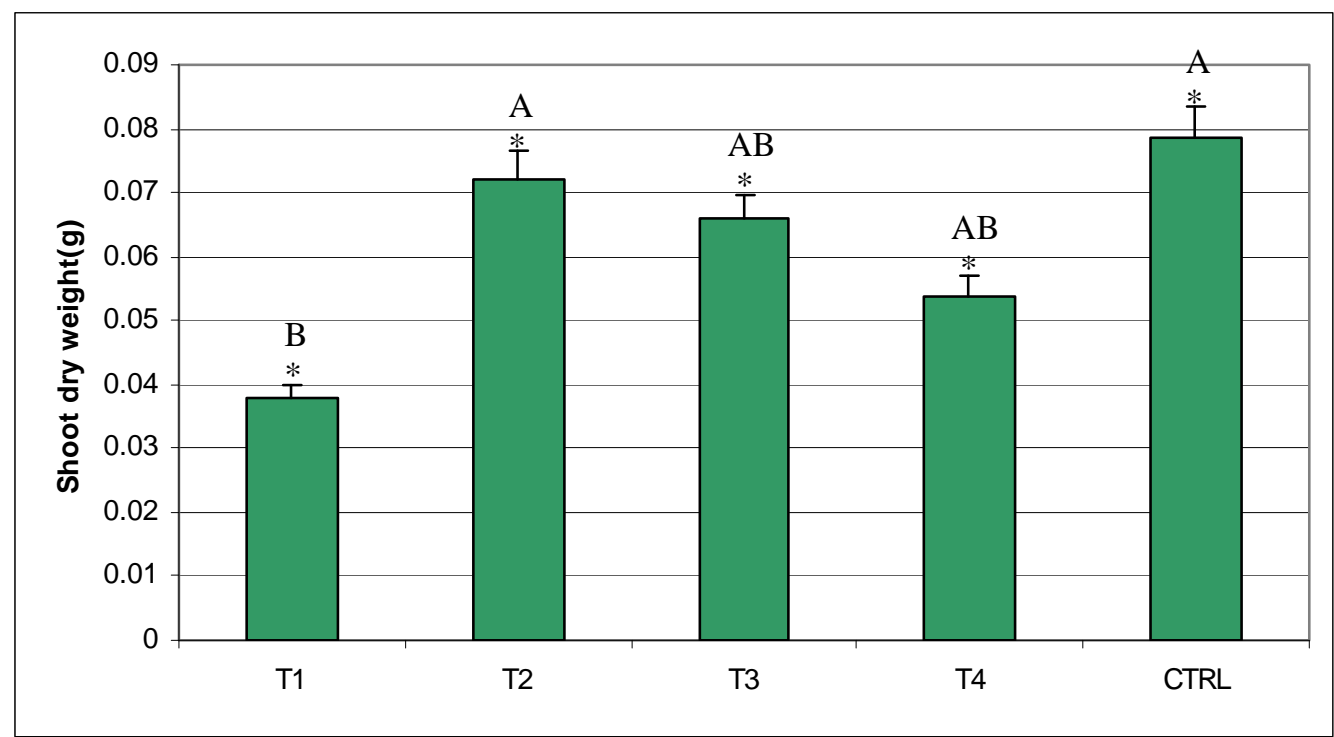

Values are mean \pm standard errors $(n=3)$. Different letters on bar graphs indicate a significant difference; $\mathrm{P}(0.05<*<0.01)$.

Fig. 3: Effect of basic slag on shoot yield of bean plants (g DW plant $\left.{ }^{-1}\right)$ for each treatment

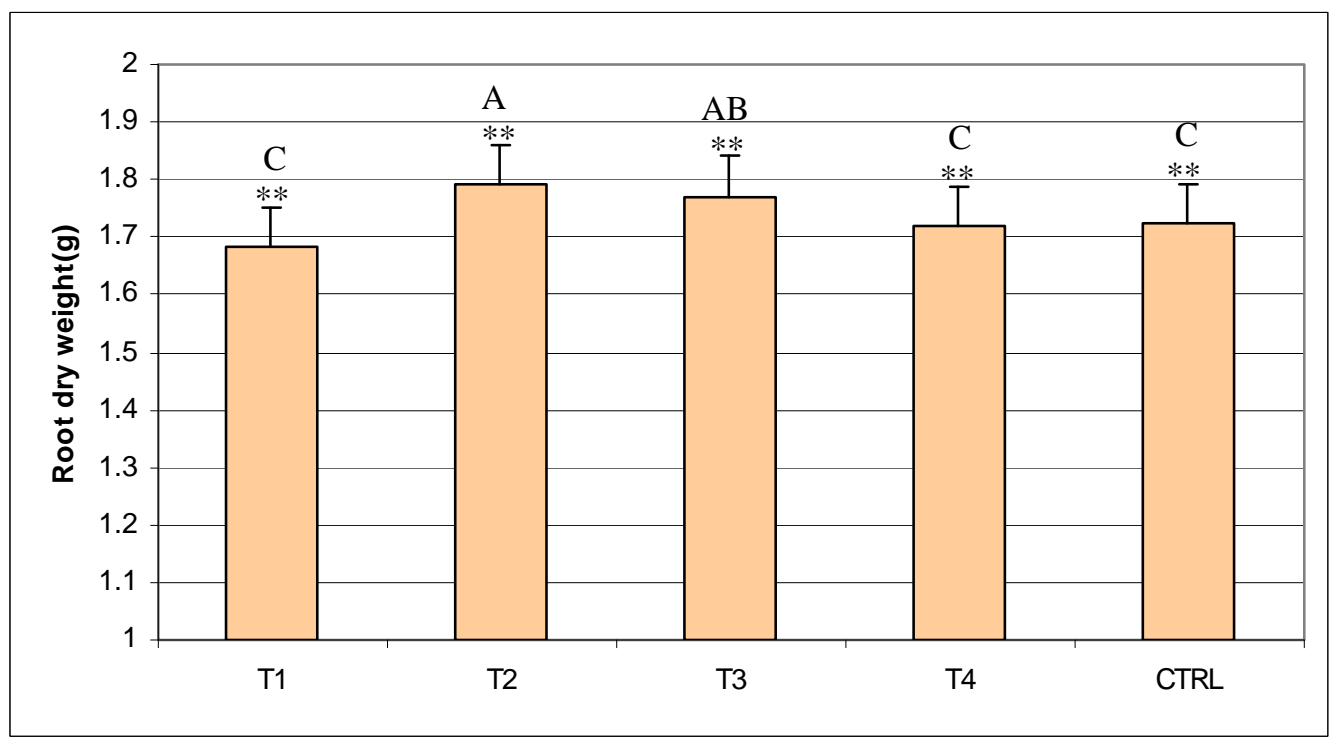

Values are mean \pm standard errors $(n=3)$. Different letters on bar graphs indicate a significant difference; $\mathrm{P}(0.01<* *<0.001)$.

Fig. 4: Effect of basic slag on root yield of bean plants (g DW plant ${ }^{-1}$ ) for each treatment 